ment has lost the services of Dr. V. B. Wigglesworth, who has been appointed director of the Insect Physiology Unit of the Agricultural Research Council ; but co-operation between these two departments continues. Dr. Wigglesworth has studied the part played by waxes in maintaining the impermeability of the insect cuticle to water and has found that some chemically inert dusts abrade the wax and thus kill insects by causing them to dry up (see Nature, 153, 493 ; 154, 333 (1944)). His Unit is also studying the action of insecticides used as sheep dips against the sheep tick, Ixodes ricinus, the water relations of this tick and the physiology of the sheep blowfly, Lucilia sericata. Field trials of D.D.T. as a sheep dip are also being made. The possible importance of work of this kind to all those who are concerned with world supplies of meat, wool and other animal products can scarcely be over-estimated.

The head of the Department of Biochemistry, Prof. H. Raistrick, has given much time to work with penicillin; he is honorary scientific adviser to the Ministry of Supply on penicillin production. This Department has also studied the deterioration of service equipment in the tropics due to the action of moulds and is searching for antibiotic substances of microbiological origin. Although patulin, prepared by the Department from Penicillium patulum, proved unable to control the common cold (see Nature, 154, 807 , Dec. 30, 1944), two other metabolic products of this mould have been isolated, namely, gentisic acid and the hitherto unknown gentisyl alcohol; the latter has been synthesized. A new antibacterial substance has been isolated from cultures of "a somewhat rare mould" which has not yet been identified with certainty; this substance appears to belong to a new type of organic compounds and its properties are being studied. Diplococcin, a new antibacterial substance formed by some strains of milk streptococci, has been isolated. It is probably, the report says, identical with a substance independently isolated at the National Dairy Research Institute, Shinfield, and described by A. T. R. Mattick and A. Hirsch (Nature, 154, 551, Oct. 28, 1944). Mattick and Hirsch found that the substance isolated by them protects mice against strains of hæmolytic streptococei virulent to mice and suggest that it may be useful for the treatment of bovine mastitis.

The appointment of Prof. J. M. Macintosh to the University of London chair of public health assures the School of vigorous and able leadership. The Association of Industrial Medical Officers is using the School more and more as its headquarters. Among researches done at the School's Department of Industrial Physiology are those on the insulating properties of clothing materials, the important question of portable sources of light, such as reading lamps, the results of which study have been published in the Transactions of the Illuminating Engineering Society, and the dangers to health of industrial dusts; advice given on the working conditions in factories has brought benefit to many workers.

The Library of the School has been busier than ever. It has increased its stock of books and pamphlets, but has experienced the difficulty of obtaining American books which is the subject of an Annotation in the Lancet $(217, \mathrm{Feb} .17,1945)$. The School also houses the Bureau of Hygiene and Tropical Diseases, the painstaking and indefatigable work of which, published in the pages of the Tropical Diseases Bulletin, the Bulletin of Hygiene and the Bulletin of War Medicine, makes available abstracts of the medical literature of every country in the world. These abstracts are done by a panel of experts, whose experience adds a critical quality which is absent from many other publications of this kind.

The Institute of Agricultural Parasitology, directed by Prof. R. T. Leiper, professor of helminthology in the School, has done much work at Winches Farm, St. Albans, on the nematode parasites of valuable crops. A catalogue of more than six hundred species of helminths parasitic in birds of economic importance has also been compiled. A method has been devised for the identification of certain nematode species from the females alone, which should be of great value to parasitologists ; and the nature and development of cestode hooks has been studied. It is at Winches Farm also that the work of that other in. valuable source of information, the Imperial Bureau of Agricultural Parasitology, is done.

Everyone will wish the School a speedy return to its normal activities when the completion of its war work makes this possible.

\section{RACIAL PROBLEMS IN AUSTRALIA}

$\mathrm{W}$ ITH the progress of civilization and the continued penetration by the white man into the domain of the coloured peoples, there comes the problem, ever increasing in intensity, of the contact and clash of conflicting customs. Men in the stone or iron age are caught up into the complicated machinery of the Western world, and the results are necessarily difficult to regulate and often disastrous to the simpler peoples.

The Anthropological Society of South Australia at its meeting in May 1944 held a conference arranged by the South Australian Division of the Australian Association of Scientific Workers, during which there was a discussion on racial problems to which Prof. J. B. Cleland contributed a valuable address. $\mathrm{He}$ pointed out that the Australian aborigines, contrary to popular belief, present a high order of intelligence, and had they not settled in a country which provided very few amenities, they would probably by now have reached a much higher stage of civilization. But what could they do in a country boasting no animal life higher than the marsupial and practically no cultivable plants? They were forced to remain nomads and with the arid conditions so frequently obtaining could make no permanent habitations.

Potentially, however, judging by a complex language and by the attainments of certain individuals, the Australian aborigine has a mental make-up not appreciably below that of the white man, though he has specialized in a different direction. There is nothing to show that erosses between them and good. class whites are likely to produce undesirable halfbreeds; the fact that many half-castes are inferior being probably due to the low-class and often vicious white men of whom they are the offspring.

There have always been attempts to guide the aborigines into European ways, but these have here. tofore led to rapid decline and death, owing in great part to lack of interest in living when removed from their native mode of life with its frequent ceremonies. It seems, in fact, impossible for the full bloods to maintain themselves in a white community, and the only hope for them is to make the few places they can call their own as inaccessible as possible to the white man. There will naturally always be certain 
adventurous spirits who will roam away and, through contact with the whites, lose touch with the old life. These newly detribalized men should be assisted to maintain themselves as respectable members of the community and to do suitable work, as much in the country as possible, on the cattle and sheep stations. They should be under some sort of supervision and be encouraged to keep up their tribal customs and corroborees.

The completely detribalized aborigines of long. standing separation from their own communities are a more difficult problem, having mostly become urbanized and of mixed blood. Prof. Cleland considers that they should not be segregated from the whites and regarded as inferiors, but should be educated to become good citizens and take their share of community life.

K. Rishbeth.

\section{PREHISTORY IN THE CONGO*}

$\mathrm{T}$ HE prehistoric archæology of the Congo is very little known. The researches of Dr. Cabu were in part published at the International Congress held in Brussels in 1935; but most of his discoveries are still unknown to the average prehistorian. Yet the Congo is probably a key area, linking as it does the north with the south of the African continent. The only bit of information on the subject which had become current among prehistorians concerned an alleged new culture, the Tumbrian; but now even this latter seems actually to be non-existent, and the industry in question merely a mélange of early, middle and later stone age material, somewhat corresponding to the Sangoan of Uganda.

It is, therefore, of very great interest to have such studies as these under notice from the pens of prehistorians of the eminence of Profs. Breuil and van Riet Lowe. Alas, there are no illustrations. Both Breuil's articles are technical, and describe in detail the industries found at a number of stone age sites and their cultural affinities. An intriguing reference occurs at the end to discoveries of painted rockshelter sites. The paintings are in red and conventionalized. Prof. van Riet Lowe also describes in detail the industries and compares them with those occurring in South Africa and in the Uganda-Kenya regions. $\mathrm{He}$, too, claims that the Tumbrian consists of "advanced Acheul, La Micoque and Combe Capelle bifaced tools (i.e., Fouresmith), ? protoStillbay, Sangoan picks, Stillbay points, Aterian and Sbäikian bifaced points (including pedunculate forms), ground and polished axes and pottery"; quite a mixture! $\mathrm{He}$ also notes the occurrence of Smithfield tools. This reinforces the contention that this culture is not purely a South African product, and backs up Archdeacon Owen's finds of a Smithfield industry in western Kenya.

Quite obviously we shall have to await the end of the War for a full account of the prehistory of the Congo. But enough is here given to make it clear that this important area is likely to be critical for any general appreciation of the Stone Ages in Africa.

M. C. BurkitT.

* "Le Paléolithique du Congo Belge d’après les recherches du Docteur Cabu". By l'A hbé Henri Breuil.

"Les industries paléolithjques de la terrasse de 15 Metres et d'un chenal secondaire comble, Plaine de Piemont de Leopoldville, d'après les fouilles et photographies du Docteur Cabu". By l'Abbé Henri Breuil.

"Notes on Dr. Francis Cabu's Collection of Stone Implements from the Belgian Congo". By Dr. C. van Riet Lowe.

Reprinted from Trans. Roy. Soc. S. Africa, 30, Pt. 2 (1944).

\section{STRAY LOSSES IN SYNCHRONOUS ELECTRICAL MACHINERY}

D. RICHARDSON, in a paper read before the Institution of Electrical Engineers in London recently, discusses the problem of eddy currents from the point of view of the effect of the physical arrangement of an alternator on the stray losses, and deals afterwards with the components of stray loss. Since the latter can be classified conveniently in accordance with their position in the alternator, the stray losses which occur in the stator are considered first.

It is shown how the arrangement of the endwindings influences the shape of the end leakage field and thus the intensity of loss in the adjacent metallic structures, and how the loss in the coreend-plate can be estimated. The effect of magnetic and non-magnetic shielding arrangements is discussed, together with details of their arrangement. Experiments in connexion with eddy-current losses in the stator end connexions are described. Consideration is given to the iron loss which occurs in the stator core under steady three-phase shortcircuit conditions owing to the flux-wave shape, and the indications are that this provides at least a partial explanation of why the stray losses can be so appreciably greater on short-circuit than on load.

The stray losses in the rotor, generally grouped under the heading of rotor surface losses, are shown to be due to several effects, notably to the concentration of ampere-conductors in one slot and to the irregularities present in the stator magnetomotive force wave. Consideration is also given to the surface or pole-face losses resulting from the 'tufting' of flux under the stator teeth, which loss is experienced under conditions of no load and is normally measured with the stator iron loss. The factors affecting the surface losses are discussed, together with methods for reducing the losses to a minimum. An indication is given of the relationship between the stray losses at the ends and those located within the core-length of an alternator, together with a description of the effect of load conditions on each of the components of stray loss.

\section{FORTHCOMING EVENTS}

Saturday, May 12

INSTITUTION OF THE RUBber INDUSTRY (MidLAND SEOTION) (at the Imperial Hotel, Birmingham), at 10 a.m. and 2 p.m.- Symposium on "The Physical and Chemical Breakdown of Rubber".

Monday, May 14

assoctation of austrian Engingers, Chemists and Solentific WORKERS IN GREAT BRITAIN (joint meeting with the ROYAL NETHERLAND INSTITUTION OF CIVII ENGINEERS AND THE SOCIETY OF DANISH Crvir ENGINEERS) (at the Institution of Structural Engineers, 11 , Upper Belgrave Street, London, S.W.1), at 6.30 p.m.-Prof. K. W' Mautner: "Extension Work on the Harbour of Dunkirk, 1930-1938" (Lantern Lecture).

Tuesday, May 15

ROYAL SOCIETY OF ARTS (DOMINIONS AND CoLONIES SECTION) (ioint meeting with the RoYAL AFrICAN SocIETY) (at John Adam Street, Adelphi, London, W.C.2), at 1.45 p.m.-Mr. Malcolm Guthrie : "Etreet, Adelphi, London, W.c.2), at 1.45 p.m.-

INSTITUTION OF ELEOTRICAL ENGINEERS (RADIO SEOTION) (at Savoy Place, Victoria Embankment, London, W.C.2), at 5.30 p.m.-Discussion on "The Characteristics of Luminescent Materials for CathodeRay Tubes" (to be opened by Mr. C. G. A. Hill).

Wednesday, May 16

ROYAL SOCIETY of ARTS (at John Adam Street, Adelphi, London, ROYAL SOCIETY of ARTS (at John Adam Street, "Thelphi, Locial RelaW.C.2), at 1.45 p.m.-Prof. J. D. Bernal, F.

tions of Science" (Trueman Wood Leture). London, W.1), at 3 p.m.--Scientiflc Papers. 